\title{
Tax Administrative Reform: Strategic Roadmap of Institutional Transformation of Directorate General of Taxation Indonesia
}

\author{
Sabila Siti Salifida ${ }^{1}$, Milla Sepliana Setyowati ${ }^{2}$ \\ \{sabilafida@gmail.com ${ }^{1}$, milla.s.setyowati@gmail.com ${ }^{2}$ \} \\ Universitas Indonesia, Indonesia ${ }^{1,2}$
}

\begin{abstract}
Directorate General of Taxation (DGT) is currently conducting institutional transformation towards Semi-Autonomous Revenue Authority (SARA) that has been formally addressed in the Blueprint of Institutional Transformation of DGT. It is addressed as the commitment to achieve the target of tax revenue. This research is addressed to analyze strategic plans in the Blueprint of Institutional transformation of DGT using qualitative approach. The research employed relevant theory such as tax administration theory, organizational transformation, strategic plans, compliance risk management, semiautonomous revenue authority, and fiscal blueprint. This research employed a literature review approach and in-depth interview. Result of the research found that strategic plans of the implementation of institutional transformation of DGT has been running accordingly in terms of strategic plans, IT and HR plans, communication, hiring and training, restructuring and reengineering, and budget allocation.
\end{abstract}

Keywords: Tax Administrative Reform, Institutional Transformation, Semi-Autonomous Revenue Authority (SARA).

\section{Introduction}

Tax revenue holds large proportions to government revenue. It shows that the Ministry of Finance, especially Directorate General of Taxation (DGT) as "collector" of tax revenue, performs significant role in achieving the target of tax revenue for the recent years. Although tax revenue has been increasing for the recent years, Directorate General of Taxation (DGT) has not achieved the target of tax revenue set in State Revenue and Expenditure until 2015. [1]

The Ministry of Finance has started the institutional transformation since 2013, including transformation of Directorate General of Taxation (DGT). The institutional transformation is one of strategic attempts to increase the tax revenue and is expected to achieve the targeted tax revenue as stated in the State Revenue and Expenditure. The program is called "Blueprint of Institutional Transformation 2014 - 2025." The blueprint has produced 87 strategic initiatives where the implementation is divided into three horizons, which are short-term transformation (2013 - 2014) as a period of building the moment of reformation, mid-term transformation (2015 - 2019) as a period of building operational and service strengths in a larger coverage, and long-term transformation $(2020-2025)$ as a period of institutionalizing the breakthrough. [2] Considering the benefit and urgency of strategic plans for the implementation of the Institutional Transformation Blueprint 2014-2025, this research is addressed to analyse the process of the 
strategic plans run by Directorate General of Taxation in implementing the strategic plans of Institutional Transformation Breakthrough.

\section{Literature Review}

European Commission-Taxation and Customs Union in the Fiscal Blueprints stated that the fiscal blueprint in 1999 was developed to be functioned as tools for European candidate countries to improve its administration capacity in adopting, applying, and sustaining legislative community to be European country member. According to Kovacs (European CommissionTaxation and Custom Union) the fiscal blueprint serves self-assessment tools that provides the whole frames and benchmark needed to assess the technical area and tax administration organization internally [2]. Basically, the blueprint serves as the benchmark in answering the questions of key indicators thus the assessment can be accurately measured.

There are two models of taxation institutions run by many countries: 1) Semi-Autonomous Revenue Authority (SARA), a system where taxation authority serves independently (autonomous) or separated from the Ministry of Finance, and 2) Non Semi-Autonomous Revenue Authority (Non-SARA), a system where taxation authority of a country is integrated with (or under) its Ministry of Finance. The difference between SARA and Non-SARA lies on procedure of policy coordination. In a SARA model, taxation authority serves independently or is separated from the ministry of finance, but still conduct policy coordination with the ministry of finance. Meanwhile in Non-SARA, the taxation authority is under coordination of the ministry of finance, where in the context of Indonesia the example of Non-SARA system is Directorate General of Taxation (DGT) and Directorate General of Customs (DGC) [3]. Nowadays a traditional structure where taxation authority serves under coordination of ministry of finance is no longer preferable. Many countries started separating tax administration from the ministry of finance (Semi-Autonomous Revenue Authority) [4].

\section{Methods}

The research employs qualitative descriptive approach. In terms of data collection, the research employs literature review approach and direct observation, through in-depth interview. The interview is conducted with Director of Internal Compliance and the Transformation of Human Capital of Directorate General of Taxation, Directorate of Transformation Management, Directorate of Business Process Transformation of Directorate General of Taxation (DGT), Section of Development of Institutional Design of Directorate of Internal Compliance and Transformation of Human Capital, Bureau of Organizational and Governance of General Secretariat of the Ministry of Finance, Change Management Officer, Sub-Organization and Governance of Organization and Internal Compliance of Secretariat of Fiscal Policy Board, academicians, and taxation practitioners. The research employs qualitative data analysis. 


\section{Analysis}

Transformation is actually required in any organizations to perform better. As realized by the Ministry of Finance, the transformation is needed to adapt with any changes, to face global challenges, to achieve targets to be equal with any similar institutions of developed countries. The transformation is also needed to sustain towards any uncertainties that may someday threaten stability of domestic economy. Thus, implementation of the institutional transformation has to be well-sustained by strategic plans to drive it towards right directions. The strategic plans are legally formulated in KMK No. 36/2014 on the Blueprint of Institutional Transformation of Directorate General of Taxation. According to Bryson, the strategic plans are divided into where we are now, where we want to go, and how to get there. The research discusses about the stage of "how to get there" detailed into six important parts which are strategic plan, IT and HR plan, communications, hiring and training, restructuring and reengineering, and budget allocation.

\subsection{Strategic Plans}

Bryson divided the strategic plans into three main parts, which are where we are now, where we want to go, and how to get there. The stage of "where we are now" is a stage where identification process is initiated with fundamental issues such as vision and mission statements of an organizations [5]. The vision of Directorate General of Taxation (DGT) has been updated to be "to be a trusted tax administration institution that treats all taxpayers fairly and delivers excellent service technology. " It can be interpreted as moving towards trusted tax administration institution by treating taxpayers fairly and by providing best technological-based services. Moreover, the mission statement of DGT is "improving the quality of life and prosperity of the people of Indonesia by; a) collecting revenues and enforcing the law to all taxpayers equally; b) facilitating tax payers to be obedient; c) pioneering the use of sophisticated technology; d) attracting and developing best in class talent." Besides identification of vision and mission issues, it is also identified current condition of working environment and organizational performance. The current situation of Directorate General of Taxation is considered to be barriers in achieving the following targets, a) manual business process leading to less-efficient activities of DGT; b) low tax ratio of Indonesia compared to other countries, and c) lack of flexibility of Directorate general of Taxation in performing activities to achieve the target of tax revenue [6]. Those conditions are expected to change after the implementation of institutional transformation.

The next stage is "where you want to go" which Directorate General of Taxation is expected to improve and update the whole business process both in terms of services and surveillance. It can be achieved by adopting digital system to promote more efficient activities. Besides that, Directorate General of Taxation is also expected to increase its tax ratio to compete with other countries. In regards with low flexibility from Directorate General of Taxation, the institutional transformation, in the form of structural separation from the ministry of finance, it is expected that Directorate General of Taxation would have stronger authority to perform better.

Achieving a goal (where do we go) from the starting point (where we are now) is called the stage of how to get there. The stage focuses on how to bridge the gap between current organization capability and the required capability to achieve desired goals. In this regard, Directorate General of Taxation breaks down the steps of "how to get there" in the blueprint of the institutional transformation.

\subsection{IT and HR Plans}


One of the strategic initiatives is to update the administration system of VAT into digital system by validating taxpayers. The validation process is conducting by ensuring the registered taxpayers are either active or not, the implementation of e-invoicing starting from registration of e-Nofa that helps real time validation process related to restitution and material validation, and electronic crediting and invoice reporting. According to Alink and Van Kommer it also includes the use of sophisticated technology internally and externally as those facilities are useful for tax officers and taxpayers in meeting their taxation obligations especially VAT [7]. The applicant of e-invoicing will be given number of invoices by the tax officers, and the invoice reporting process of electronic taxation is performed by taxpayers themselves.

Besides that, other initiatives of DGT is to improve tax offices quality by improving efficiency and effectiveness of SPT (letter of declaration) management, standardizing document management process, and upgrading the capacity of storage of particular tax documents. One of the programs is to issue regulation in terms of format and procedure of document digitalization and archiving. According to Alink and Van Kommer the process is categorized as the use of internal IT. It is also run by improving the quality of human capital especially for tax officers from Directorate General of Taxation assigned in the Integrated Service Provisions (ISP) through Training of Technical Substantive Specialization, Service Officers in 11 Financial Training Office, and 1 Centre of Education and Training of Taxation with total 365 staffs as participants. The program is addressed to produce more professional tax officers to perform more efficient contribution and to achieve the goal of tax administration.

The next initiative is to enlarge the coverage of Data Processing Centre and to improve capability of data acquisition. Additional number of taxpayers accompanied by the increase number of compliances drive higher burden for Directorate General of Taxation in terms of tax administration and SPT (letter of declaration) management. Even though DJP has developed system of electronic SPT (letter of declaration), paper SPT still actually exists and the existence would burden the administration of tax offices. Tax offices would forward paper documents to Data Processing Unit and Taxation Document for digitalization process, data entry, and storage. Meanwhile others are managed separately by tax offices where taxpayers are registered, and it takes long process to be done. Moreover, the obstacles are that SPT management is constrained by recording applications and is only few numbers of scientific research of SPT (letter of declaration that should have conducted by tax offices that receive SPT. Thus, Directorate General of Taxation massively promote the institutional transformation to accelerate digitalization process. According to Alink and Van Kommer, the process is classified into infrastructure of internal IT.

The next initiative is the migration of taxpayers to e-filling in order to reduce administration burdens and to improve process efficiency, in terms of time length, to proceed the SPT (letter of declaration). Moreover, the initiative is also run by improving the capacity of contact centre and functionality of website. The transformation of contact centre is one by giving the authority to information and complaint services office of Directorate General of Taxation. One example is outbound call which is information provision to public in order to improve compliance. Meanwhile in terms of extending functionality of website, it is done by providing detail information regarding taxation in the website. Besides that, public can download and print out any tax forms they want to. In terms of human resource Alink and Van Kommer expressed that besides depending on IT infrastructure, tax administration should be also backed up by reliable human capital to respond any feedback from the public. Directorate General of Taxation has been improving the quality of human capital in order improve the quality of services to the taxpayers. 
The next strategic initiative is to harmonize functional staffs and improve their capacity. According to the diagnose output from the selected consultant, stock of human capital that performs surveillance functions in Directorate General of Taxation (especially supervision and account representative) is way below the standard, which has been confirmed by Directorate General of Taxation themselves. According to Alink and Van Kommer besides depending on IT infrastructure, tax administration must also rely on human capital to respond any feedbacks from the public. It can be indicated that development of information and technology would perform well if it is accompanied by development of the human capital. DGT has been improving digitalization process so that the human resources can be redirected to surveillance function. That way it is expected to strengthen surveillance function towards tax compliance in order to achieve the targeted tax revenue.

\subsection{Communication}

The integrated communication strategy is addressed to increase tax compliance through education and socialization to taxpayers. It is also accompanied by publication of tax law enforcement through mass media and improve positive image of Directorate General of Taxation through upgrading of communication strategy and management of current issues proactively. According to Alink and Van Kommer tax administration has to address mutual understanding with taxpayers. Improving positive image is one of strategies of Directorate General of Taxation to build and maintain mutual relationship with taxpayers.

\subsection{Hiring and Planning}

Even though DGT requires new staffs to offset significant increase in taxpayers, DGT has not been able to conduct recruitment and staff hiring independently as it serves under the ministry of finance, thus the whole recruitment and hiring processes are handled by the Ministry of Administrative and Bureaucratic Reform. Meanwhile training is addressed to improve the effectiveness of billing activities so that human capital of DGT can improve to face any dynamics. Alink and Van Kommer expressed that training is addressed to produce professional tax officers by implementing sustainable and systematic training processes to improve knowledge and capability in providing efficient and effective services to achieve the targeted tax administration goals.

The next initiative is to ensure quality and consistency of law enforcement by improving the quality of human capital based on their area of interest and expertise. It means Directorate General of Taxation is expected to conduct training based on area of expertise to improve the competency and the quality so that professional human capital can be produced to create more effective and efficient law enforcement.

\subsection{Restructuring and Engineering}

In implementing the institutional transformation of IT and HR, Directorate General of Taxation formulated it in the blueprint of institutional transformation and is realized in some strategic initiatives. One of those initiatives is to upgrade segmentation and model of taxpayer coverage. Segmentation is conducted so that placement of taxpayers can be updated regularly and move urban taxpayer coverage towards electronic-based and contact center, while taxpayers in other regions would be equipped with alternative channel such as mobile tax unit. Referring 
to the case it is seen that Directorate General of Taxation currently implement reengineering process that involve upgrading business process for service quality improvement.

The next initiative is to reach informal economy through end to end approach by identifying informal sector of the highest potential tax and by establishing special task force to manage any activities in DGT. It is based on the data analyzed by Directorate of Extension of Directorate General of Taxation. The data consists of active business sectors which are feasible to develop. It is also done to integrate the NPWP (Taxpayers Identification Number) with data of NIK (employment number) to meet the need of data/information integration. Reengineering is addressed to improve performance of Directorate General of Taxation.

Besides that, other important initiative is to develop risk-based predictive compliance model related to business process. Based on the Annual Report of Institutional Transformation Program of Directorate General of Taxation, the formulation of the initiative is addressed to accelerate the accomplishment of the target set by Directorate General of Taxation through development of Compliance Risk Management (CRM). According to the theory of Alink and Van Kommer (2011), Directorate General of Taxation needs to calculate any potential risks that may come up from the extent to which taxpayers comply or meet their tax obligations.

The next strategic initiative is to involve third party from data, law enforcement, and taxpayer coverage. As a country that embrace self-assessment tax system, Indonesia gives full authority to taxpayers to comply their tax obligations. DGT requires data and information to measure compliance of taxpayers so that the self-assessment system would run accordingly. Development of the initiative is addressed to develop and to strengthen external partnership of data distribution, taxpayer coverage, and law enforcement to increase tax revenue and improve compliance of taxpayers. Directorate General of Taxation conducts a reengineering process where the involvement of the third party for data, law enforcement, and taxpayer coverage as the output of re-brainstorming process and improvement of business process to achieve the targeted performance, service quality, and service responses.

The next initiative is organizational restructuration. It is mentioned in the Annual Report of Institutional Transformation Program that there are some internal weaknesses that can be identified from the existing organization structure such as those related to span of control of Director General of Taxation. It leads to a focus distraction from strategic issues that should have become priority of the organization and also overlapping duties of echelon II unit functions. It would potentially generate inefficiency in the process of organization. DGT has added three more directorates which are Directorate of International Taxation, Directorate of Law Enforcement, and Directorate Intelligent of Taxation. Changes in the structure or organization of Directorate General of Taxation can be expressed as restructuring process due to changes from the old structure to new structure. These changes are expected to generate better performance for Directorate General of Taxation.

The next strategic initiative is the flexibility needed for the institutional transformation. The institutional transformation is initiated by awareness of Directorate General of Taxation that requires high organizational flexibility to manage number of important aspects in DGT such human capital, remuneration, and budgeting. Current condition that places Directorate General of Taxation under the Ministry of Finance considered to provide less-flexibility compared to independent position DGT could have. Under the ministry of finance, Directorate General of Taxation has to synchronize the whole programs with the ministry of finance. The system of Semi-Autonomous Revenue Authority is actually required for DGT to create more flexibility to achieve the target of tax revenue. According to Mann (2004) the implementation of SARA would generate higher benefit such as the increase in tax ratio; improvement of efficiency of public resource management through financial authority and administrative authority, 
recruitment of competent staffs, discipline, increase in minimum wage, tax administration improvement, improvement of tax credibility and governance in general towards better culture of administration that are proactive and professional; comprehensive calculations to all types of tax as well as integration of tax and taxpayer database. The benefits of SARA would serve as the answer of current problems faced by Directorate General of Taxation. Nevertheless, in order to avoid any abuse of taxing power, there has to be relevant regulation about limiting the taxing power. The formulating team should be separated from the executors. In the other hand the formulation of the regulation has to be handled by independent board, separated from Directorate General of Taxation. Tax administration institution and tax policy should be separated like those implemented in other countries.

\subsection{Budget Allocation}

Mardiasmo expressed that budget is actually a statement of performance target that needs to be achieved within certain period of time stated in financial measurement, while budgeting is a process or method to prepare the budget. [6] According to Didiek as confimed by Yandiawan, budgeting process has been well performing in the institutional transformation program. Nevertheless, the current budget has some limitation. Of the targeted revenue by Rp. 1,300 trillion, budget for DGT is Rp. 7 trillion. Instead according to Yandiawan (2017) ideal budget for tax authority referring to international taxation board is $2 \%$ from the targeted tax revenue.

Some obstacles and barriers related data collection and acquisition come up due to ineffectiveness of the program of institutional transformation, thus budget allocation for DGT is not as optimum as expected. In terms of organizational performance, Directorate General of Taxation still needs to improve its performance in implementing the institutional transformation. It affects the incompleteness of data collections.

\section{Conclusion}

Strategic plans of the Blueprint of Institutional Transformation of Directorate General of Taxation have been formulated and executed based on theory from Bryson. The implementation is initiated in three stages which are "where are we now" by identifying organizational vision and mission as well current condition of DGT, the next is the stage of "where you want to be" by providing some alternatives of changes target DGT wish to proceed, and stage of "how to get there" formulated in the blueprint of institutional transformation. Moreover, in regards with IT and HR plans, it is developed improvement of services from manual system to digital system. In the other hand human capital quality is also improved to produce more competent tax officers. In terms of communications, the institutional transformation is done by creating positive image of DGT. In terms of hiring and training, even though DGT does not have independent authority to conduct recruitment, DGT has currently conducted training themselves for the improvement of quality of human capital. The next is in terms of restructuring and reengineering, it is done by improving business process and organizational structure of DGT towards Semi-Autonomous Revenue Authority. Moreover, budget allocation is still constrained by limited budget for Directorate General of Taxation. 


\section{References}

[1] K. Keuangan, "Realisasi Pendapatan Negara Tahun 2014 Capai Rp 1.537,2 Triliun,” Retrieved from Kementerian Keuangan Republik Indonesia. .

[2] E. T. and C. U. . F. B. Commission, "A Path to a Robust Modern and Efficient Tax Administration," vol. 9, 2007.

[3] W. Saputra and A. Maftuchan, "Kelembagaan dan Tata Kelola Perpajakan Perlu Perubahan," 2015.

[4] H. Darussalam, Kristiaji, B. B., \& Klise, "Desain Kelembagaan Administrasi Perpajakan: Perlukah Ditjen Pajak Terpisah dari Kementerian Keuangan? InsideTax. pp. 6. Juli-Agustus," 2013.

[5] J. M. Bryson, Strategic planning for public and nonprofit organizations: A guide to strengthening and sustaining organizational achievement. John Wiley \& Sons, 2018

[6] M. Kidd and W. J. Crandall, Revenue administration: A toolkit for implementing a revenue authority. International Monetary Fund, 2010.

[7] M. Alink and V. Van Kommer, Handbook on tax administration. IBFD, 2011. 